DOI https://doi.org/10.30525/978-9934-26-047-6-39

\title{
SEARCH FOR COMPOUNDS WITH PROTEIN TYROSINE KINASE ACTIVITY AMONG SULFUR-AND NITROGEN-CONTAINING DERIVATIVES OF 9,10-ANTHRACENEDIONE
}

\author{
Stasevych M. V. \\ Doctor of Chemical Sciences, Associate Professor, \\ Associate Professor at the Department of Technology of Biologically Active \\ Substances, Pharmacy and Biotechnology \\ Lviv Polytechnic National University \\ Zvarych V. I. \\ Candidate of Chemical Sciences, \\ Senior Researcher at the Department of Technology of Biologically Active \\ Substances, Pharmacy and Biotechnology \\ Lviv Polytechnic National University \\ Lviv, Ukraine
}

Protein tyrosine kinase (PTK) is one of the main signaling enzymes in the process of cell signal transduction, which catalyzes the transfer of ATP$\gamma$-phosphate to the tyrosine residues of the substrate protein, phosphorrylating it, regulating cell growth, differentiation, death, the development of pathological processes, as well as a number of other physiological and biochemical processes [1].

PTK dysfunction can cause several diseases in a living organism. It is known that more than $50 \%$ of metabolic products containing protooncogenes and oncogenes have PTK activity, and their abnormal expression leads to dysregulation of cell proliferation, causing tumorigenesis [2]. Also, abnormal PTK elevations are associated with tumor invasion and metastasis, tumor neovascularization, and resistance to tumor chemotherapy [3]. Currently, more than 300 PTK inhibitors are used by clinicians in various therapies [4, 5], but a number of side effects and economic factors limit their practical use. Therefore, the development and research of new PTK inhibitors remain an urgent task.

Taking into account that among the 9,10-anthracenedione derivatives only some representatives of PTK inhibitors have been identified [6-9]. Hence, the study of newly synthesized derivatives of 9,10-dioxoanthracene as protein tyrosine kinase inhibitors is promising.

The tyrosine kinase activity of 9,10-anthracenedione compounds with thioureid [10], amino acid [11], azole [12, 13], dithiocarbamate [14] and hydrazone [15] fragments was studied regarding the effect of these derivatives on TPK receptors capable of uncontrolled activation with 
oncogenesis. Testing was carried out on the fraction of membrane proteins of muscle tissue cells of healthy nonlinear rats exposed to the test compounds at a concentration of $100 \mu \mathrm{m}$ [16]. Experimental testing has established that all the studied derivatives in various range exhibit an inhibitory effect on the tyrosine kinases activity.

Among the derivatives of 9,10-anthracenedione with thioureid, amino acid, thiazole and 1,2,4-triazole substituents, the greatest inhibitory effect on the membrane-bound tyrosine protein kinase activity was caused by compounds 1-4, for which inhibition is $75 \%, 82 \%, 77 \%$ and $76 \%$, respectively (Fig. 1).<smiles>CC(C)CC(NCC(=O)Nc1cccc2c1C(=O)c1ccccc1C2=O)C(=O)O</smiles><smiles>CSCCC(NCC(=O)Nc1cccc2c1C(=O)c1ccccc1C2=O)C(=O)O</smiles><smiles>CC(C)NCC(=O)Nc1cccc2c1C(=O)c1ccccc1C2=O</smiles><smiles>Cc1cs/c(=N\C(=O)c2ccccc2)n1-c1cccc2c1C(=O)c1ccccc1C2=O</smiles>

Fig. 1. Inhibitors of PTK among derivatives of 9,10 -anthracenedione with thioureid, amino acid, thiazole and 1,2,4-triazole substituents

Among the derivatives of 9,10-anthracenediones with 1,2,3-triazole, dithiocarbamate and hydrazone fragments, two dithiocarbamates 5, 6 and 1,2,3-triazole 9 have been found with a pronounced inhibitory effect on membrane tyrosine protein kinases in the range of $17-22 \%$ (Fig. 2), while for other studied compounds this effect has not observed under the experimental conditions.

The effect of the above-mentioned compounds on the activity of cytosolic PTKs was also investigated, and compound $\mathbf{9}$ among the triazole derivatives with the best inhibitory effect of $28 \%$ has been identified (Fig. 2).

Dithiocarbamates 6-8 showed a slightly weaker effect with regard to inhibition of the cytosolic PTK activity at the level of $12-20 \%$, while hydrazone derivatives [15] practically did not show the effect. 

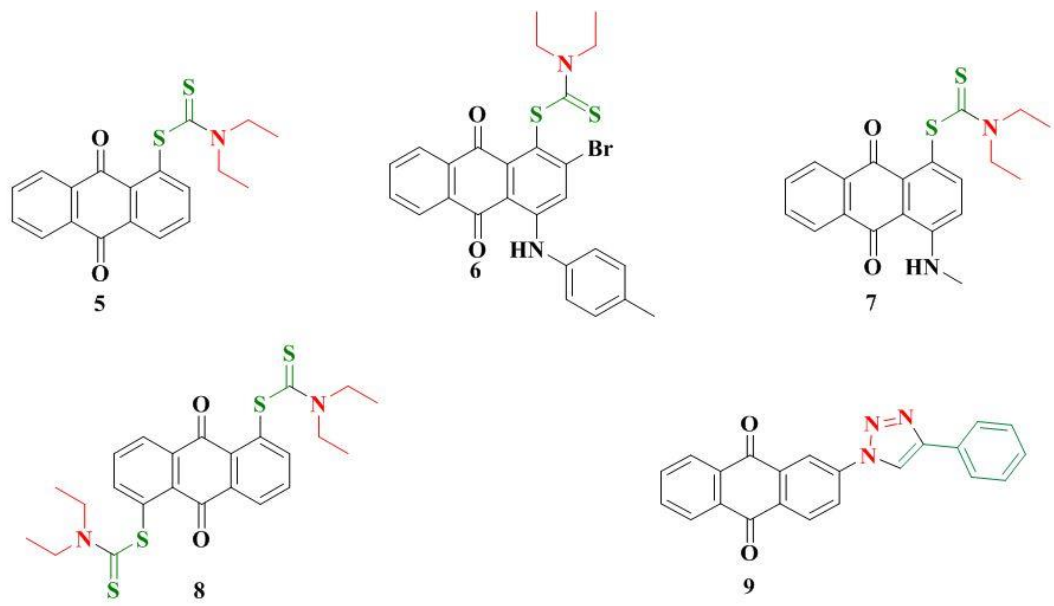

Fig. 2. Compounds with an inhibitory effect on the activity of membrane and cytosolic tyrosine protein kinases among derivatives of 9,10-anthracenedione with 1,2,3-triazole and dithiocarbamate fragments

Thus, the study of 9,10-anthracenedione compounds with thioureid, amino acid, azole, dithiocarbamate and hydrazone fragments has been carried in order to search for new potential inhibitors of protein tyrosine kinases to establish the effect of the structure of the test substance on the manifestation of protein tyrosine kinase action and to identify promising hitcompounds for in-depth studies for further structural modifications.

\section{References:}

1. Jiao Q., Bi L., Ren Y., Song S., Wang Q., Wang Y. S. Advances in studies of tyrosine kinase inhibitors and their acquired resistance. Molecular Cancer. 2018. № 17. 36.

2. Drake J. M., Lee J. K., Witte O. N. Clinical targeting of mutated and wild-type protein tyrosine kinases in cancer. Mol. Cell. Biol. 2014. № 34. P. 1722-1732.

3. Knösel T., Kampmann E., Kirchner T., Altendorf-Hofmann A. Tyrosinkinasen in weichgewebstumoren. Der Pathologe. 2014. № 35. P. $198-201$.

4. Al-Obeidi F., Lam K. Development of inhibitors for protein tyrosine kinases. Oncogene. 2000. № 19. P. 5690-5701.

5. Zámečníkova A. Novel approaches to the development of tyrosine kinase inhibitors and their role in the fight against cancer. Expert Opinion on Drug Discovery. 2013. № 9. P. 1-16. 
6. Lown J. W. Anthracycline and Anthracendione-based Anticancer Agents. Amsterdam: Elsevier Science Publ. B. V., 1988. 752 p.

7. Jayasuriya H., Koonchanok N. M., Geahlen R. L., McLaughlin J. L., Chang C.-J. Emodin, a protein tyrosine kinase inhibitor from Polygonum cuspidatum. J. Nat. Prod. 1992. № 55. P. 696-698.

8. De Moliner E., Moro S., Sarno S., Zagotto G., Zanotti G., Pinna L. A., Battistutta R. Inhibition of protein kinase CK2 by anthraquinone-related compounds. A structural insight. J. Biol. Chem. 2003. № 278. P. 1831-1836.

9. Almutairi M. S., Hegazy G. H., Haiba M. E., Ali H. I., Khalifa N. M., Soliman A. E. M. Synthesis, docking and biological activities of novel hybrids celecoxib and anthraquinone analogs as potent cytotoxic agents. International Journal of Molecular Sciences. 2014. № 15. P. 22580-22603.

10. Stasevych M., Zvarych V., Musyanovych R., Novikov V., Vovk M. Synthesis of N-benzoyl-N'-(9,10-dioxo-9,10-dihydroanthracene-1-yl)thioureas and quantum-chemical analysis of the reaction passing. Chemistry and Chemical Technology. 2014. № 8. P. 135-140.

11. Zvarich V. I., Stasevich M. V., Stan'ko O. V., KomarovskayaPorokhnyavets E. Z., Poroikov V. V., Rudik A. V., Lagunin A. A., Vovk M. V., Novikov V. P. Computerized prediction, synthesis, and antimicrobial activity of new amino-acid derivatives of 2-chloro- $\mathrm{N}$ (9,10-dioxo-9,10-dihydroanthracen-1-yl)acetamide. Pharm. Chem. J. 2014. № 48. P. 584-588.

12. Stasevych M. V., Zvarych V. I., Stan'ko O. V., Vovk M. V., Novikov V. P. Synthesis of 2-( $N$-benzoylimino)- $N$-(9,10-dioxo-9,10-dihydroanthracen-1-yl)thiazoles. Chem. Heterocycl. Compd. 2014. № 49. P. 1831-1833.

13. Stasevych M., Zvarych V., Lunin V., Vovk M., Novikov V. The new 1,2,3-triazolylantracene-9,10-diones: synthesis and computer bioactivity screening. Chemistry \& Chemical technology. 2017. № 11. P. 1-9.

14. Zvarych V., Stasevych M., Lunin V., Deniz N. G., Sayil C., Ozyurek M., Guclu K., Vovk M., Novikov V. Synthesis and investigation of antioxidant activity of the dithiocarbamates derivatives of 9,10-anthracenedione. Monatshefte für Chemie. 2016. № 147. P. 2093-2101.

15. Stasevych M., Zvarych V., Lunin V., Kopak N., KomarovskaPorokhnyavets O., Deniz N. G., Sayil C., Ozyurek M., Guclu K., Vovk M., Novikov V. Synthesis, investigation of antimicrobial and antioxidant activity of anthraquinonylhydrazones. Monatshefte für Chemie. 2018. № 149. P. 1111-1119.

16. Halenova T. I., Nikolaeva I. V., Stasevych M. V., Zvarych V. I., Lunin V. V., Novikov V. P., Savchuk O. M. Platelet aggregation under the influence of some dithiocarbamate derivatives of 9,10-anthracenedione. Research Journal of Pharmaceutical, Biological and Chemical Sciences. 2017. № 8. P. 1626-1632. 